\title{
Benthic carbon fixation and cycling in diffuse hydrothermal and background sediments in the Bransfield Strait, Antarctica
}

\author{
Clare Woulds $^{1}$, James B. Bell ${ }^{1,2}$, Adrian G. Glover ${ }^{3}$, Steven Bouillon ${ }^{4}$, and Louise S. Brown ${ }^{1,2}$ \\ ${ }^{1}$ School of Geography, University of Leeds, Leeds, LS2 9JT, UK \\ ${ }^{2}$ Cefas, Pakefield Road, Lowestoft, Suffolk, NR33 0HT, UK \\ ${ }^{3}$ Life Sciences Department, Natural History Museum, Cromwell Rd, London SW7 5BD, UK \\ ${ }^{4}$ Department of Earth and Environmental Sciences, KU Leuven, Leuven, Belgium
}

Correspondence: Clare Woulds (c.woulds@leeds.ac.uk)

Received: 21 May 2019 - Discussion started: 7 June 2019

Revised: 29 August 2019 - Accepted: 13 September 2019 - Published: 2 January 2020

\begin{abstract}
Sedimented hydrothermal vents are likely to be widespread compared to hard substrate hot vents. They host chemosynthetic microbial communities which fix inorganic carbon (C) at the seafloor, as well as a wide range of macroinfauna, including vent-obligate and background nonvent taxa. There are no previous direct observations of carbon cycling at a sedimented hydrothermal vent. We conducted ${ }^{13} \mathrm{C}$ isotope tracing experiments at three sedimented sites in the Bransfield Strait, Antarctica, which showed different degrees of hydrothermalism. Two experimental treatments were applied, with ${ }^{13} \mathrm{C}$ added as either algal detritus (photosynthetic C), or as bicarbonate (substrate for benthic $\mathrm{C}$ fixation). Algal ${ }^{13} \mathrm{C}$ was taken up by both bacteria and metazoan macrofaunal, but its dominant fate was respiration, as observed at deeper and more food-limited sites elsewhere. Rates of ${ }^{13} \mathrm{C}$ uptake and respiration suggested that the diffuse hydrothermal site was not the hot spot of benthic $\mathrm{C}$ cycling that we hypothesised it would be. Fixation of inorganic $\mathrm{C}$ into bacterial biomass was observed at all sites, and was measurable at two out of three sites. At all sites, newly fixed C was transferred to metazoan macrofauna. Fixation rates were relatively low compared with similar experiments elsewhere; thus, $\mathrm{C}$ fixed at the seafloor was a minor $\mathrm{C}$ source for the benthic ecosystem. However, as the greatest amount of benthic C fixation occurred at the "Off Vent" (non-hydrothermal) site $\left(0.077 \pm 0.034 \mathrm{mg} \mathrm{C} \mathrm{m}^{-2}\right.$ fixed during $\left.60 \mathrm{~h}\right)$, we suggest that benthic fixation of inorganic $\mathrm{C}$ is more widespread than previously thought, and warrants further study.
\end{abstract}

\section{Introduction}

Sedimented hydrothermal vent (SHV) sites are areas where hydrothermal fluid diffuses through soft sediment cover on its way to mixing with oceanic bottom water. This creates hot (up to $\sim 100^{\circ} \mathrm{C}$ ) sediments with porewaters rich in dissolved sulfide and methane. This supports microbes that conduct chemosynthetic $\mathrm{C}$ fixation via a range of pathways (Bernardino et al., 2012). These hydrothermally influenced sediments are likely to be more spatially extensive than hard substrate vents, although their diffusive nature makes their extent hard to quantify. Sedimented hydrothermal vents have been shown to influence biological community composition and nutrition at adjacent sites which were otherwise characterised as "inactive" or "off-vent" (Levin et al., 2009; Bell et al., 2016a, b, 2017a). However, the ecology of sedimented hydrothermal sites has received relatively little study. There is only one modelling study that has focused on the interaction between benthic ecosystems and C cycling at SHVs (Bell et al., 2017b), and there are no direct observations of SHV C cycling by components of the benthic ecosystem.

So far, a limited number of studies have used natural stable isotopic analysis to determine carbon sources and their fixation pathways utilised by infauna at SHVs (Levin et al., 2009; Soto, 2009; Sweetman et al., 2013; Bell et al., 2016a; Portail et al., 2016). Evidence has shown that $C$ fixed during the anaerobic oxidation of methane, oxic methanotrophy, sulfide oxidation, as well photosynthetic organic matter (OM) sinking from the surface, are all utilised by macrofauna to varying extents at SHVs (Levin et al., 2009; Bernardino et al., 2012). 
It is challenging to quantify the relative contributions of different $\mathrm{C}$ sources to macrofaunal diets, both because the natural isotopic ranges of some $\mathrm{C}$ sources overlap, and because often the isotopic compositions of those end-members could not be measured (Levin et al., 2009; Bell et al., 2016a). Unknown variability in trophic discrimination factors also currently precludes quantitative estimates of the relative contribution of different $\mathrm{C}$ sources.

Stable isotope tracing experiments offer a way to overcome some of these issues. The experimental addition of labelled $\mathrm{C}$ sources, either photosynthetic $\mathrm{OM}$ or dissolved inorganic C (bicarbonate) to SHV sediment allows for the production of chemosynthetic OM, and the transfer of different $\mathrm{OM}$ types into the macrobenthos and other $\mathrm{C}$ pools in the short term to be directly observed. Such experiments (using only photosynthetic $\mathrm{OM}$ ) have been conducted at a wide range of (ostensibly) non-chemosynthetic benthic sites, and have shown a wide variation in the relative importance of different biological C processing pathways (Woulds et al., 2009, 2016). At food-limited sites in the deep sea, respiration tends to be the dominant fate of added OM (van Oevelen et al., 2011, 2012). Shallower, more food-rich settings such as coastal fjords and estuaries, with greater sedimentary organic $\mathrm{C}$ concentrations and higher macrofaunal biomass, show a pattern of biological $\mathrm{C}$ processing in which uptake by fauna is a more important process, and at unusual and particularly food-rich sites, such as the lower margin of the Arabian Sea oxygen minimum zone ( $\sim 1000 \mathrm{~m}$ depth), macrofaunal $\mathrm{C}$ uptake can even be the dominant process (Woulds et al., 2009, 2016).

The occurrence of chemosynthesis in a benthic habitat represents an additional source of fresh, labile OM in an environment that would otherwise be more severely food limited. For this reason, it has been suggested that hydrothermally influenced sites can be biomass hot spots, where biogeochemical cycling is rapid (Bernardino et al., 2012). However, due to the environmental toxicity created by hydrothermal fluid, and the fact that the majority of taxa inhabiting SHVs are background rather than vent endemic, the difference in faunal biomass between SHVs and adjacent non-vent sites is highly variable (Levin et al., 2009; Bernardino et al., 2012; Bell et al., 2016b). Therefore, it seems possible that biological C processing at SHVs will show a distinct complement of biological $\mathrm{C}$ processing patterns unlike those observed elsewhere in the deep sea. The food-rich, high-biomass characteristics of some SHVs may lead to biological C processing that is more similar to shallower, food-rich environments. On the contrary, spatially variable biomass patterns, as well as the metabolic costs associated with potentially high temperatures and porewater toxicity could counteract the effect of enhanced food availability. As direct measurements of biological $\mathrm{C}$ processing rates and pathways have not previously been made at SHVs or in the Southern Ocean, a gap remains in our understanding of sedimentary $\mathrm{C}$ and $\mathrm{N}$ cycling.

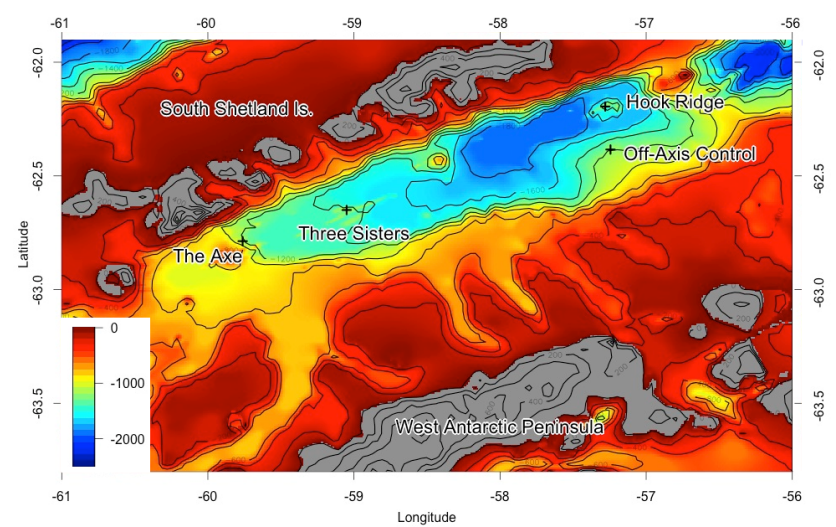

Figure 1. Map of study sites, adapted from Bell et al. (2016b). The "Off Vent" site is marked "Off-Axis Control", and the Middle Sister site is located where "Three Sisters" is marked. Depths in metres.

In this study we conducted stable isotope tracing experiments at three sites of variable hydrothermal activity in the Bransfield Strait, Antarctica. To the best of our knowledge this is the first isotope tracing experiment in this type of system. The following hypotheses were tested:

- Hydrothermally influenced sites exhibiting chemosynthesis will show elevated rates of biological $\mathrm{C}$ processing.

- At hydrothermally influenced sites bicarbonate will be fixed by chemoautotrophs and transferred to the macrofauna.

- Preference for feeding on photosynthetic versus chemosynthetic OM will be taxon dependent.

\section{Methods}

\subsection{Study sites}

In this study we focus on a SHV in the Bransfield Strait, close to the tip of the Antarctic Peninsula. The discovery of hydrothermal venting in the Bransfield Strait was reported by Klinkhammer et al. (2001), who detected hydrothermal plumes in the water column, and recovered hot "soupy" sediment from Hook Ridge. In addition, a species of Sclerolinum (Sahling et al., 2005; Georgieva et al., 2015) has been described there, and porewater geochemistry and hydrothermal flux rates have been published (Sahling et al., 2005; Aquilina et al., 2013).

Experiments were conducted at three sites in the Bransfield Strait, Antarctica (Fig. 1). Two of the sites lay on raised edifices, known as Hook Ridge and Middle Sister, along the axis of the basin, and were selected as being likely to exhibit diffuse hydrothermal venting, and the former was the location where diffuse venting had been identified. A third site, at a similar depth but along the north side of the basin, 
was chosen as an off-vent control (hereafter known as "Off Vent").

Porewater geochemistry at Middle Sister and Off Vent were consistent with microbial processes without the influence of hydrothermal activity. Porewater $\mathrm{NO}_{3}^{-}$and $\mathrm{NH}_{4}^{+}$profiles were indicative of nitrate reduction, but downcore declines in $\mathrm{SO}_{4}^{2-}$ and $\mathrm{Cl}^{-}$were lacking over the $\sim 40 \mathrm{~cm}$ depth sampled. In contrast, at Hook Ridge $\mathrm{SO}_{4}^{2-}$ was depleted by up to $11 \%$ compared with seawater, and $\mathrm{Cl}^{-}$was depleted by up to $7 \%$, allowing for the calculation of hydrothermal advection of 9-33 $\mathrm{cm} \mathrm{yr}^{-1}$ (Aquilina et al., 2013).

Sediment organic carbon $\left(\mathrm{C}_{\text {org }}\right)$ concentrations were lower at Hook Ridge $\left(0.97 \mathrm{wt} \% \mathrm{C}_{\text {org }}\right)$ than at the Off Vent and Middle Sister sites, which showed similar values (1.35 wt \% and $1.4 \mathrm{wt} \% \mathrm{C}_{\mathrm{org}}$ respectively; Table 1). The sites differed in biomass of different groups, with Hook Ridge and Middle Sister showing higher bacterial biomass and lower macrofaunal biomass than the Off Vent site (Table 1). Hook Ridge was the only site classified as hydrothermally active by Aquilina et al. (2013). Porewaters were enriched in sulfide, methane and dissolved metals and depleted in chloride. Macrofauna tended to be representative of the background taxa of the region. Polychaetes were numerically dominant (41\%-56\%), except at Hook Ridge, which was dominated by peracarids. Oligochaetes were the next most dominant at all sites. Ventendemic fauna were represented by two species of siboglinid polychaete $-S$. contortum at Hook Ridge, and Siboglinum sp. elsewhere - and they were always a minority constituent of the community.

\subsection{Isotope tracing experiments}

Sediment cores (10 cm internal diameter) were recovered using a multiple corer, and kept in the dark at seafloor temperatures (Table 1) using cooled incubators. Experiments were initiated by the addition of isotopically enriched substrates. Cores were then sealed and incubated for $\sim 60 \mathrm{~h}$, during which core-top water was continuously stirred.

Duplicate cores were subjected to each of two treatments. In the "algae" treatment, lyophilised algal cells (Chlorella, Cambridge Isotope Laboratories, CNLM-455-1) enriched in ${ }^{13} \mathrm{C}$ and ${ }^{15} \mathrm{~N}$ (both $\sim 100$ atom $\%$ ) were allowed to settle on the sediment surface, giving a final dose of $436 \pm$ $30 \mathrm{mg} \mathrm{Cm}^{-2}$. This was equivalent to $\sim 1.6 \%$ of total $\mathrm{OC}$ in the surface $1 \mathrm{~cm}$ of sediment, or $\sim 9 \%$ of the annual OC input (Bell et al., 2017b). It is recognised that such organic detritus is less degraded than the sinking photosynthetic material which normally reaches the depths of our study sites. This is a limitation of the method common to all such experiments in the literature, and means that rates for processing of added $\mathrm{C}$ in algae experiments should be considered maximal. Further, diatom detritus would have been more representative of local photosynthetic material, but was unfortunately not available.
In the "bicarbonate" treatment a solution of $100 \%{ }^{13} \mathrm{C}$ labelled sodium bicarbonate and $100 \%{ }^{15} \mathrm{~N}$ labelled ammonium chloride was injected into the surface $5 \mathrm{~cm}$ of sediment porewater, to give a dose of $306 \mathrm{mg} \mathrm{Cm}^{-2}$ and $2.52 \mathrm{mg} \mathrm{N} \mathrm{m}^{-2}$, and an estimated porewater bicarbonate concentration of $1 \mathrm{mM}$.

At intervals ( $T_{0}$ and every $\sim 12 \mathrm{~h}$ thereafter) during the incubation, core-top water samples were withdrawn from algae treatment cores, and stored in crimp-cap vials poisoned with $\mathrm{HgCl}_{2}$ for dissolved inorganic carbon (DIC) analysis. At the end of the experiment cores were extruded and sectioned at intervals of $0-1,1-2,2-3,3-5$ and $5-10 \mathrm{~cm}$. Half of each section was frozen at $-20^{\circ} \mathrm{C}$, and the other half was preserved in buffered $10 \%$ formalin.

\subsection{Sample processing and analysis}

Overlying water samples were analysed for the concentration and isotopic composition of DIC in triplicate on a Thermalox TOC analyser coupled to a Thermo DELTA V Advantage IRMS via a Conflo IV interface, using a Thermo TriPlus autosampler. The reaction column was filled with $\mathrm{H}_{3} \mathrm{PO}_{4}$ coated beads.

Frozen sediment samples were freeze dried, and surface 0-1 cm horizons were analysed for phospholipid fatty acids (PLFAs) following Main et al. (2015). Briefly, samples were extracted in a modified Bligh and Dyer extraction solution of chloroform : methanol : citrate buffer $(1: 2: 0.8)$. The polar fraction was obtained by loading samples onto ISOLUTE SPE columns, washing with chloroform and acetone, and eluting with methanol. After the addition of nonadecanoic acid (C19:0) as an internal standard, extracts were derivatised in the presence of $\mathrm{KOH}$ in methanol. Derivatisation was quenched with water and acetic acid, and the organic fraction was extracted by washing with $4: 1$ isohexane : chloroform. Samples were dried and then taken up in isohexane for analysis on a TRACE Ultra GC, connected via a GC Combustion III to a DELTA V Advantage IRMS (Thermo Finnigan, Bremen). The isotopic signature of each PLFA was measured against a $\mathrm{CO}_{2}$ reference gas which is traceable to IAEA reference material NBS 19 (TS-Limestone), with a precision of $\pm 0.31 \%$, and corrected for the $\mathrm{C}$ atom added during derivatisation.

Sediment horizons between 0 and $10 \mathrm{~cm}$ preserved in formalin were sieved over a $300 \mu \mathrm{m}$ mesh. Macrofauna were extracted under a binocular microscope, identified to broad taxonomic level, air dried in pre-weighed tin capsules, and weighed. In some cases multiple individuals were pooled to create samples large enough for analysis. Fauna were decarbonated by dropwise addition of $0.1 \mathrm{M} \mathrm{HCl}$, followed by air drying at $50^{\circ} \mathrm{C}$. Calcareous foraminifera and bivalves that were too small for manual removal of shells were decarbonated with $6 \mathrm{~N} \mathrm{HCl}$. Fauna were analysed for their $\mathrm{C}$ content and isotopic signature using a FlashEA 1112 series elemental analyser connected via a Conflo III to a DELTA ${ }^{\text {Plus }}$ 
Table 1. Site characteristics, all of the information except that on bacterial biomass is from Bell et al. (2016b).

\begin{tabular}{lllrrrrr}
\hline Site & Latitude & Longitude & $\begin{array}{r}\text { Depth } \\
(\mathrm{m})\end{array}$ & $\begin{array}{r}\text { Temperature } \\
\left({ }^{\circ} \mathrm{C}\right)\end{array}$ & $\begin{array}{r}\text { Sediment wt \% Corg } \\
\text { in 0-1 cm horizon }\end{array}$ & $\begin{array}{r}\text { Macrofaunal Biomass } \\
\left(\mathrm{mg} \mathrm{Cm}^{-2}\right)\end{array}$ & $\begin{array}{r}\text { Bacterial Biomass } \\
\left(\mathrm{mg} \mathrm{Cm}^{-2}\right)\end{array}$ \\
\hline Off Vent & $62.3842^{\circ} \mathrm{S}$ & $57.2440^{\circ} \mathrm{W}$ & 1150 & 0 & 1.35 & 1091 \\
Hook Ridge & $62.1924^{\circ} \mathrm{S}$ & $57.2783^{\circ} \mathrm{W}$ & 1054 & 1 & 0.97 & $314 \pm 145$ \\
Middle Sister & $62.6552^{\circ} \mathrm{S}$ & $59.0502^{\circ} \mathrm{W}$ & 1311 & 0 & 1.40 & $451 \pm 21$ \\
\hline
\end{tabular}

XP isotope ratio mass spectrometer (all Thermo Finnigan, Bremen). Carbon contents was quantified using the area under the mass spectrometer response curve, against $\mathrm{Na}$ tional Institute of Standards and Technology reference material 1547 peach leaves (repeat analysis gave a precision of $\pm 0.35 \%$ ). Isotopic data were traceable to IAEA reference materials USGS40 and USGS41 (both L-glutamic acid), with a precision of $\pm 0.13 \%$.

\subsection{Data treatment}

Respiration of added algal $\mathrm{C}$ was calculated for cores subjected to the algae treatment. The amount of excess $\mathrm{DI}^{13} \mathrm{C}$ in each sample was calculated by first subtracting the natural abundance of ${ }^{13} \mathrm{C}$ in DIC. This was scaled up to give the total amount of DIC from the added algae at each sample time point, and corrected for water removed and added during sampling. The respiration rate was calculated for each core by placing a line of best fit through the amount of added ${ }^{13} \mathrm{C}$ over time, and normalised to surface area.

Bacterial incorporation of ${ }^{13} \mathrm{C}$ was calculated by first subtracting the natural abundance of ${ }^{13} \mathrm{C}$ from the isotopic signature of each PLFA (data published in Bell et al., 2017a), where the difference exceeded the precision of the analytical technique, to give the amount of added $\mathrm{C}$ in each compound. Bacterial incorporation was then calculated using the four bacteria-specific PLFAs isoC14:0, isoC15:0, antisoC15 : 0 and isoC16:0, following Boschker and Middelburg (2002). Uptake of ${ }^{13} \mathrm{C}$ into these bacteria-specific PLFAs was summed, and scaled up on the basis that they together account for $14 \%$ of total bacterial PLFA, and that PLFAs account for $5.6 \%$ of total bacterial biomass. For samples in the bicarbonate treatment further upscaling was applied, to account for the fact that the addition of ${ }^{13} \mathrm{C}$ bicarbonate was calculated to result in a porewater DIC pool that was 22 atom $\%{ }^{13} \mathrm{C}$.

Faunal uptake of added ${ }^{13} \mathrm{C}$ was calculated by subtracting ${ }^{13} \mathrm{C}$ attributable to its natural abundance in the appropriate taxon (data published in Bell et al., 2017a) from faunal isotopic signatures, where the difference exceeded the precision of the analytical technique, and multiplying by the quantity of organic $\mathrm{C}$ in each specimen. Specimens were summed for each core, and the value was multiplied by 2 to account for only half of each horizon being used for faunal extraction.

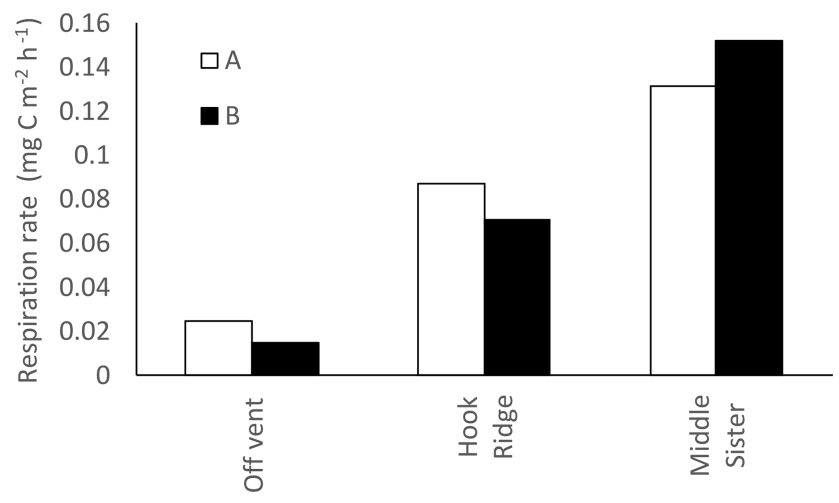

Figure 2. Respiration rates measured in algae addition experiments. $\mathrm{A}$ and $\mathrm{B}$ refer to the two replicate cores in each experiment.

\section{Results}

Data files can be accessed at https://doi.org/10/dgsn (Woulds et al., 2019).

\subsection{Respiration}

Respiration rates measured in algae addition experiments varied from $0.03 \mathrm{mg} \mathrm{Cm}^{-2} \mathrm{~h}^{-1}$ at the Off Vent site to $0.15 \mathrm{mg} \mathrm{Cm}^{-2} \mathrm{~h}^{-1}$ at Middle Sister (Fig. 2).

\subsection{Bacterial uptake and PLFA suite}

In the algae addition experiments, total bacterial uptake of $\mathrm{C}$ throughout the experiment was maximal at Middle Sister and Hook Ridge (1.30-1.91 and $1.25 \mathrm{mg} \mathrm{Cm}^{-2}$ respectively), and minimal at the Off Vent site $\left(0.25-0.77 \mathrm{mg} \mathrm{Cm}^{-2}\right.$, Fig. 3). In bicarbonate addition experiments, in which incorporation of ${ }^{13} \mathrm{C}$ into bacterial PLFAs represents chemosynthesis, bacterial incorporation of bicarbonate was maximal at the Off Vent site $\left(0.05-0.10 \mathrm{mgCm}^{-2}\right)$, and was also detectable in one of the replicates at Middle Sister $\left(0.003 \mathrm{mg} \mathrm{C} \mathrm{m}^{-2}\right.$, which was close to detection limits, so this value is treated with caution); however, bacterial incorporation of bicarbonate was not detectable at Hook Ridge.

The PLFA suites at all sites were qualitatively similar. They were dominated by C16:0, C16: $1 \omega 7 \mathrm{c}$ and C18 : $1 \omega 7$, which together constituted $42 \pm 2 \%$ of total PLFAs (Fig. 4). This is at the high end of contributions from these compounds elsewhere, such as $34 \%-45 \%$ in the Arabian Sea 

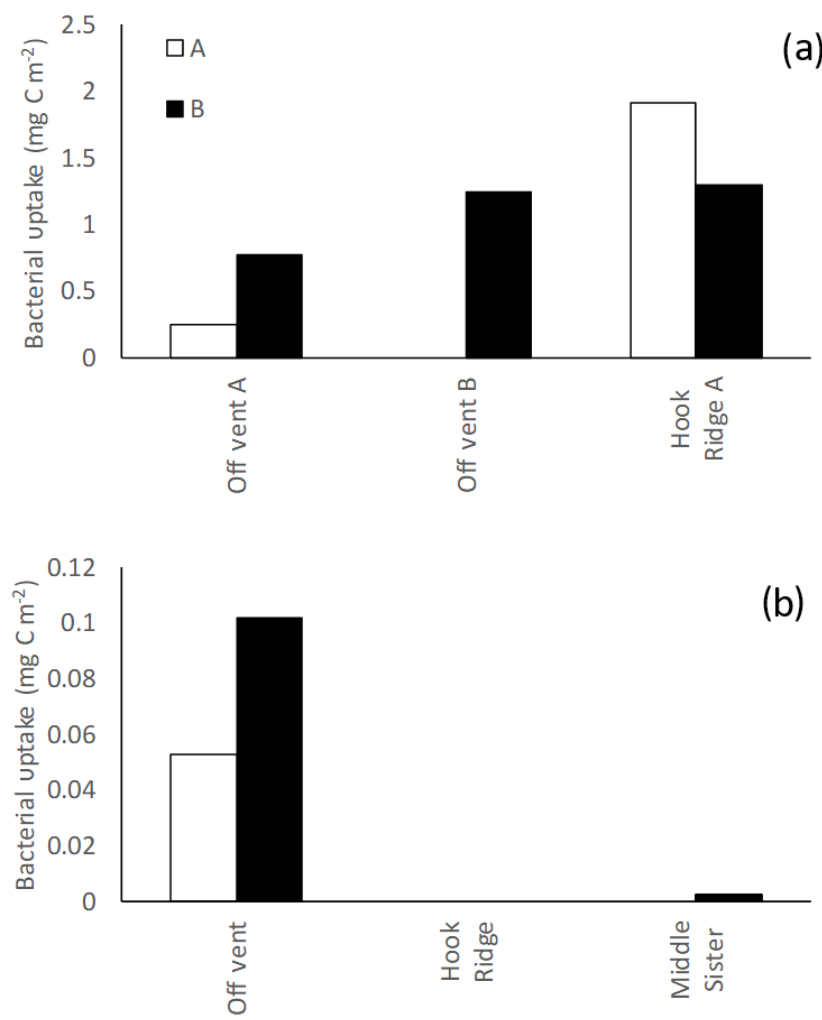

Figure 3. Bacterial uptake measured in (a) algae addition experiments and (b) bicarbonate addition experiments. Uptake was not quantifiable at Hook Ridge B and Middle Sister A, and a sample was not available from Hook Ridge A. A and B refer to the two replicate cores in each experiment.

and $41 \%$ on the Galicia Bank (Kunihiro et al., 2014). The relatively high proportions of $\mathrm{C} 16: 1 \omega 7$ and $\mathrm{C} 18: 1 \omega 7$ are indicative of the presence of chemosynthetic and specifically sulfide oxidising bacteria (Colaco et al., 2007). In addition $\mathrm{C} 18: 1 \omega 9$, which is linked to endosymbionts in vent mussels, and $\mathrm{C} 18: 1 \omega 13$, which is associated with methylotrophic bacteria, were also present (Colaco et al., 2007).

In both algae and bicarbonate addition experiments, ${ }^{13} \mathrm{C}$ incorporation into PLFAs was dominated by $\mathrm{C} 16: 0$, followed by $\mathrm{C} 18: 1 \omega 9$ and the sulfide oxidiser indicators $\mathrm{C} 16$ : $1 \omega 7$ and $\mathrm{C} 18: 1 \omega 7$ (Fig. 4).

\subsection{Faunal uptake}

Faunal uptake of added $\mathrm{C}$ differed between the A and B replicate cores in all experiments except the algae addition at the Off Vent site, and bicarbonate addition at Middle Sister (Fig. 5).

In algae addition experiments faunal uptake was similar between the Off Vent site and one of the Hook Ridge cores $\left(\sim 0.03 \mathrm{mg} \mathrm{C} \mathrm{m}^{-2}\right)$, whereas the other Hook Ridge core showed very low faunal $\mathrm{C}$ uptake. Considerably greater fau- nal uptake $\left(0.12 \mathrm{mg} \mathrm{Cm}^{-2}\right)$ was observed in one of the replicate cores from Middle Sister (Fig. 5).

In bicarbonate addition experiments, measurable uptake of ${ }^{13} \mathrm{C}$ by fauna was observed at all sites. It was maximal at Hook Ridge $\left(0.02 \mathrm{mg} \mathrm{Cm}^{-2}\right.$ in one replicate), and the Off Vent and Middle Sister sites showed similar values (Table 2, Fig. 5).

The small size of individuals meant that organisms had to be pooled for isotopic analysis, limiting the taxonomic resolution of the faunal uptake data. Although limited in this way, the data show that faunal uptake of ${ }^{13} \mathrm{C}$ in both algae and bicarbonate addition experiments was mostly carried out by either polychaetes, or "mixed macrofauna" (Fig. 6). This latter category contained variously bivalves, crustaceans, echinoderms, nematodes and foraminifera, in cases where the groups were not present in sufficient numbers to enable separate reporting of their $\mathrm{C}$ uptake. When a group was present in a sufficient quantity, it was analysed separately. As with total macrofaunal ${ }^{13} \mathrm{C}$ uptake, there was considerable variability between replicate cores in the most abundant taxonomic groups. In addition, meiofaunal organisms took up ${ }^{13} \mathrm{C}$ at Middle Sister, and the bicarbonate ${ }^{13} \mathrm{C}$ that was transferred to macrofauna at Hook Ridge was mostly observed in amphipod crustaceans.

\section{Discussion}

\subsection{Occurrence of inorganic $\mathrm{C}$ fixation}

The results of the bicarbonate addition experiments show evidence for the occurrence of benthic $\mathrm{C}$ fixation at all sites, and transfer of that $\mathrm{C}$ to the macrofauna, in the form of isotopic enrichment of bacterial PLFAs at the Off Vent and Middle Sister sites (Fig. 3), and of macrofauna at the Hook Ridge and Middle Sister sites (Fig. 5). The quantities of bicarbonate ${ }^{13} \mathrm{C}$ detected in bacterial and faunal biomass were low, and tended to be 1 to 2 orders of magnitude smaller than equivalent values for the algae addition experiments (Table 2). We have confidence that the values reported are above detection limits, in that data were only used for areas where the enrichment of organisms or PLFAs above their natural background signatures was greater than the analytical precision of the method. The greatest quantities of bacterial uptake were measured at the Off Vent site (Fig. 3), and the greatest quantity transferred to the fauna was measured at Hook Ridge (Fig. 5); however, due to the low values measured and the evident patchiness of faunal communities, we do not feel these differences are suitable for further discussion.

The most striking result of the bicarbonate addition experiments was that evidence for benthic $\mathrm{C}$ fixation was found at all sites, not only at the hydrothermally influenced Hook Ridge. Further, the site showing the largest amount of bicarbonate ${ }^{13} \mathrm{C}$ incorporation into bacterial PLFAs was the Off Vent "control" site (Table 2, Fig. 3). This is consistent 

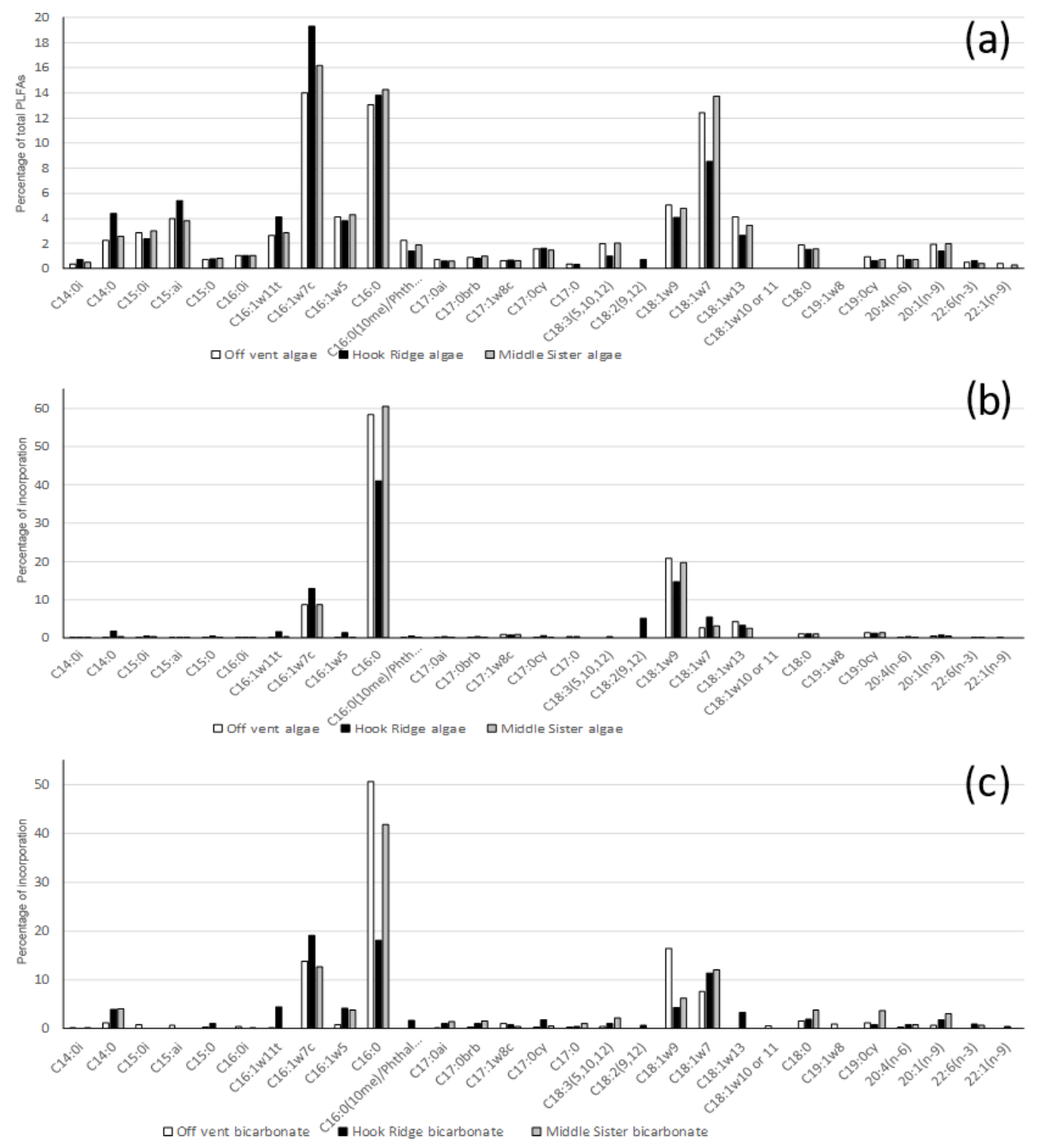

Figure 4. Example PLFA suites - each data series is from one sample, as opposed to being an average across two replicates. (a) PLFA suite as percentage of the total PLFAs in the algae addition experiments (figure for bicarbonate addition experiments very similar and not shown). (b) The composition of ${ }^{13} \mathrm{C}$ uptake into PLFAs in algae addition experiments. (c) The composition of ${ }^{13} \mathrm{C}$ uptake into PLFAs in bicarbonate addition experiments.

with the occurrence of siboglinids at all sites. These host chemosynthetic endosymbionts, most of which conduct sulfide oxidation (Thornhill et al., 2008; Georgieva et al., 2015). It should be noted that the evidence for inorganic $\mathrm{C}$ fixation comes from PLFAs in the bulk sediment, while isotopic signatures of siboglinids did not show enrichment above background values. Therefore, the occurrence of benthic C fixation is not only associated with siboglinids.

Experiments were designed to replicate natural conditions as far as practically possible, while being limited to shipboard rather than in situ methods. One result of this is that the sediment contained in cores was detached from the upward flux of hydrothermal fluid, and the electron donors it supplied. This could have limited inorganic $\mathrm{C}$ fixation, which would have impacted the rates measured at Hook Ridge. We suggest, however, that this is not a serious limitation, as Hook
Ridge was rather mildly hydrothermal. Vent-endemic fauna were almost absent (Bell et al., 2016b), there was no increase in faunal biomass close to venting, downcore profiles of alkalinity, nitrate and ammonium were consistent with normal microbial processes, and hydrothermal advection rates were 9-33 $\mathrm{cm} \mathrm{yr}^{-1}$ (Aquilina et al., 2013). At these low advection rates we suggest that there would not have been sufficient time during our $\sim 60 \mathrm{~h}$ experiments for a noticeable depletion in the availability of electron donors supplied by hydrothermal fluid.

The evidence suggests that while the amount of benthic C fixation was always low, it was not restricted to environments typically thought of as chemosynthetic (sedimented or hard substrate hydrothermal vents, methane seeps or organic falls; Bernardino et al., 2012). Thus, benthic C fixation appears to play a role in benthic $\mathrm{C}$ cycling at a much wider 
Table 2. Amount of $\mathrm{C}$ in pools at the end of the experiment, and respiration rates (algae addition experiments only). N/A indicates that it was not appropriate to measure respiration in bicarbonate addition experiments, n.d. indicates no data due to missing sample, and "low" indicates an unmeasurably low value. The value marked $*$ indicates detectable bacterial ${ }^{13} \mathrm{C}$ uptake, but very close to detection limits - thus, the value should be treated with caution.

\begin{tabular}{llllll}
\hline Site & $\begin{array}{l}\text { Treatment and } \\
\text { replicate }\end{array}$ & $\begin{array}{l}\text { Amount respired } \\
\left(\mathrm{mgCm}^{-2}\right)\end{array}$ & $\begin{array}{l}\text { Respiration rate } \\
\left(\mathrm{mgCm}^{-2} \mathrm{~h}^{-1}\right)\end{array}$ & $\begin{array}{l}\text { Bacterial uptake } \\
\left(\mathrm{mgC} \mathrm{m}^{-2}\right)\end{array}$ & $\begin{array}{l}\text { Macrofaunal uptake } \\
\left(\mathrm{mg} \mathrm{Cm}^{-2}\right)\end{array}$ \\
\hline Off Vent & Algae A & 1.23 & 0.025 & 0.25 & 0.027 \\
Off Vent & Algae B & 0.75 & 0.015 & 0.77 & 0.034 \\
Off Vent & Bicarbonate A & N/A & N/A & 0.053 & 0.0009 \\
Off Vent & Bicarbonate B & N/A & N/A & 0.102 & low \\
Hook Ridge & Algae A & 4.97 & 0.087 & n.d. & 0.033 \\
Hook Ridge & Algae B & 4.06 & 0.071 & 1.25 & 0.003 \\
Hook Ridge & Bicarbonate A & N/A & N/A & n.d. & 0.021 \\
Hook Ridge & Bicarbonate B & N/A & N/A & low & 10 low \\
Middle Sister & Algae A & 7.16 & 0.13 & 1.91 & 0.004 \\
Middle Sister & Algae B & 8.37 & 0.15 & 1.30 & 0.12 \\
Middle Sister & Bicarbonate A & N/A & N/A & 0.00 & 0.003 \\
Middle Sister & Bicarbonate B & N/A & N/A & $0.003 *$ & 0.003 \\
\hline
\end{tabular}
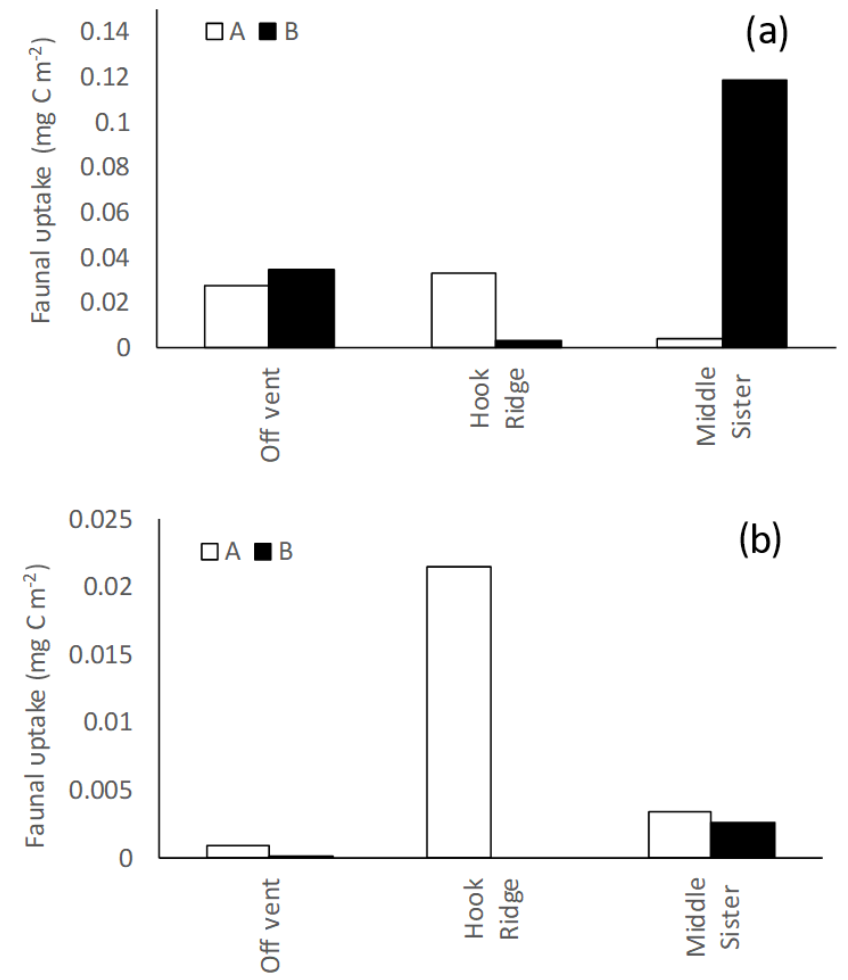

Figure 5. Faunal uptake in (a) algae addition experiments and (b) bicarbonate addition experiments. A and B refer to the two replicate cores in each experiment.

range of sites and over a much larger area of the seafloor than previously thought. This is supported by linear inverse modelling of $\mathrm{C}$ cycling at the sites in this study, which led Bell et al. (2017b) to suggest that chemosynthetic support for ecosystems may have a far greater spatial extent than

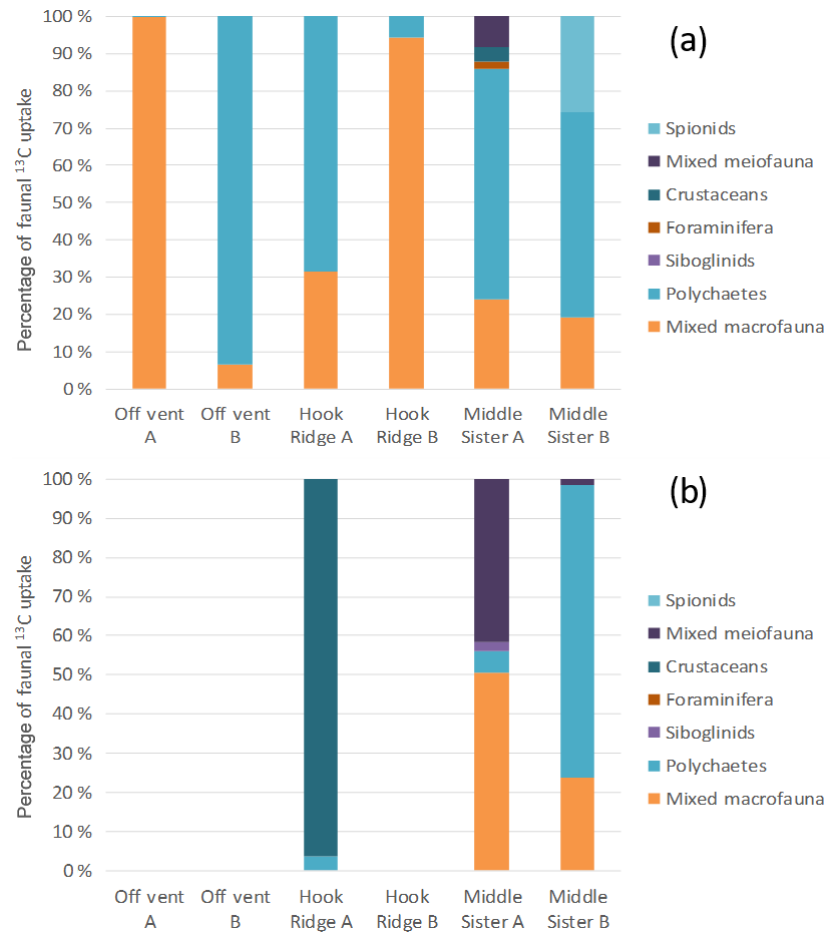

Figure 6. Distribution of $\mathrm{C}$ uptake amongst taxonomic groups in the (a) algae addition experiments and (b) bicarbonate addition experiments.

previously thought, extending beyond those which are directly hydrothermally influenced. Similar results have also been reported in non-hydrothermal, but methane-rich sediments on the South Georgia margin, where the assimilation of ${ }^{13} \mathrm{C}$ labelled bicarbonate into bacterial biomass and transfer into macrofauna was also observed (Would et al., 2019). 
In addition, in situ observations of benthic $\mathrm{C}$ fixation have also been made at mesotrophic, abyssal sites in the eastern equatorial Pacific, which were not associated with hydrothermal or methane seep activity (Sweetman et al., 2018). In that study incorporation of ${ }^{13} \mathrm{C}$ labelled bicarbonate into bacterial PLFAs was observed at two sites separated by hundreds of kilometres, at rates similar to bacterial assimilation of phytodetritus $\mathrm{C}$ at the same sites. Together with global-scale modelling completed by Middelburg (2011), these studies suggest that chemoautotrophic $\mathrm{C}$ fixation may be considerably more widespread than previously thought. It is, therefore, deserving of further study so that it can be quantitatively incorporated into our understanding of the marine $\mathrm{C}$ cycle.

In their study using linear inverse modelling of the benthic food web and $\mathrm{C}$ cycle, based on natural isotopic and biomass data, Bell et al. (2017b) modelled a rate for chemosynthesis of $5.76-8.4 \mathrm{mg} \mathrm{C} \mathrm{m}^{-2} \mathrm{~d}^{-1}$ at Hook Ridge and $<0.006 \mathrm{mg} \mathrm{C} \mathrm{m}^{-2} \mathrm{~d}^{-1}$ at the Off Vent site. These modelled rates at Hook Ridge are considerably higher than Hook Ridge benthic $\mathrm{C}$ fixation measured in this study, for which there was evidence (labelled PLFAs), but a rate could not be calculated. The higher modelled rates by Bell et al. (2017b) may be explained by the fact that a temperature of $50^{\circ} \mathrm{C}$ was used for the Hook Ridge site, based on previously published conditions for the site (Klinkhammer et al., 2001). Unfortunately, equipment was not available while at sea for measurement of sediment temperature at the study sites; therefore, all experiments, including that at Hook Ridge, were conducted at measured bottom water temperatures of $0-1{ }^{\circ} \mathrm{C}$. It is likely that the rates measured here for chemosynthetic incorporation of labelled bicarbonate are lower than those that would have been measured in situ. It is also probable that measurable rates could have been detected at Hook Ridge had more samples been available for replicate analyses.

The maximal rate of benthic $\mathrm{C}$ fixation measured in this study was $0.050 \mathrm{mg} \mathrm{C} \mathrm{m}^{-2} \mathrm{~d}^{-1}$, which occurred in one core at the Off Vent site. This value remains considerably lower than the $0.24-1.02 \mathrm{mg} \mathrm{Cm}^{-2} \mathrm{~d}^{-1}$ measured by Molari et al. (2013; rates calculated in Sweetman et al., 2018) at depths ranging between 1207 and $4381 \mathrm{~m}$ on the Iberian margin and in the Mediterranean, and the $1.29 \mathrm{mg} \mathrm{Cm}^{-2} \mathrm{~d}^{-1}$ measured by Sweetman et al. (2018) at a depth of approximately $4100 \mathrm{~m}$ in the Clarion Clipperton Zone. The Bransfield Strait sites in this study were shallower, had higher concentrations of sedimentary organic $\mathrm{C}$ and slightly lower bottom water temperatures than either of the previous studies cited. The very low temperatures at which experiments were conducted $\left(1^{\circ} \mathrm{C}\right.$ at Hook Ridge and $0{ }^{\circ} \mathrm{C}$ at the Off Vent site) are likely to have contributed to the slow rates of benthic $\mathrm{C}$ fixation measured. Another factor which may influence benthic $\mathrm{C}$ fixation is the annual flux of photosynthetic $\mathrm{C}$ from the surface (Molari et al., 2013; Bell et al., 2017a). The annual flux of POC to the sediments in the Bransfield Strait is greater than in the Clarion Clipperton Zone, and probably than in the Mediterranean as well (Masque et al., 2002; Sweetman et al., 2017), and this may be an additional driver behind the low benthic $\mathrm{C}$ fixation rates observed. Archaeal abundance has been shown to correlate with dark $\mathrm{C}$ fixation, and addition of labile organic material has been shown to increase inorganic $\mathrm{C}$ fixation rates, perhaps via a combination of heterotrophy and mixotrophy (Molari et al., 2013). Overall, the factors governing benthic $\mathrm{C}$ fixation rates require investigation. In addition, the pathways (i.e. autotrophic $\mathrm{C}$ fixation versus anapleurotic $\mathrm{C}$ fixation by heterotrophs, Wegener et al., 2012), energy sources (e.g. sulfide and methane) and organisms responsible for benthic inorganic $\mathrm{C}$ fixation have not been identified, and warrant further study.

\subsection{Carbon uptake by macrofauna}

Uptake of added C by fauna in isotope tracer experiments usually shows a degree of spatial patchiness (e.g. Woulds et al., 2007), but this seems to have been particularly marked in the Bransfield Strait, mainly at those sites with hydrothermal influence. This is consistent with the patchiness of S. contortum in replicate cores at Hook Ridge (Bell et al., 2016b). At both Hook Ridge and Middle Sister there was a very marked difference in faunal uptake of algal $\mathrm{C}$ between the $\mathrm{A}$ and $\mathrm{B}$ replicate cores in the algae addition experiments (Fig. 5), and this was considerably greater than that observed, for example, in experiments on the Pakistan margin (Woulds et al., 2007). This is likely due to differences in the biomass of fauna present in each core, and such marked small-scale patchiness in faunal communities has been noted previously as a particular feature of SHVs (Levin et al., 2009; Bernardino et al., 2012). Fine-scale distribution of fauna is related to variations in concentrations of substrates such as sulfide and methane (Levin et al., 2003); therefore, the patchiness observed, especially at Hook Ridge, is likely related to spatial and temporal fluctuation in hydrothermal advection.

Faunal uptake of added $\mathrm{C}$ appeared to be greatest at Middle Sister in the algae addition experiments, and at Hook Ridge in the bicarbonate addition experiments; however, the variation between replicate cores limits the conclusions that can be drawn. Previous isotope tracing experiments have noted correlations between the biomass of taxa and the amount of $C$ that they take up (e.g. Woulds et al., 2007). Further, there was no systematic variation in biomass-specific $\mathrm{C}$ uptake (0.026-0.13 $\mu \mathrm{g} \mathrm{C}$ uptake / $\mathrm{mg} \mathrm{C} \mathrm{biomass)} \mathrm{between}$ sites; therefore, the patterns observed here in faunal $\mathrm{C}$ uptake are likely to have resulted from variation in the biomass present in each experimental core.

Similarly, the identities of fauna responsible for ${ }^{13} \mathrm{C}$ uptake were variable between replicate cores (Fig. 6), and this is also likely to have been driven by variation in the macrofaunal community present in each core. The prevalence and variable importance of the "mixed macrofauna" category indicates that a fairly diverse assemblage was engaged in $\mathrm{C}$ uptake and processing in some cases. 


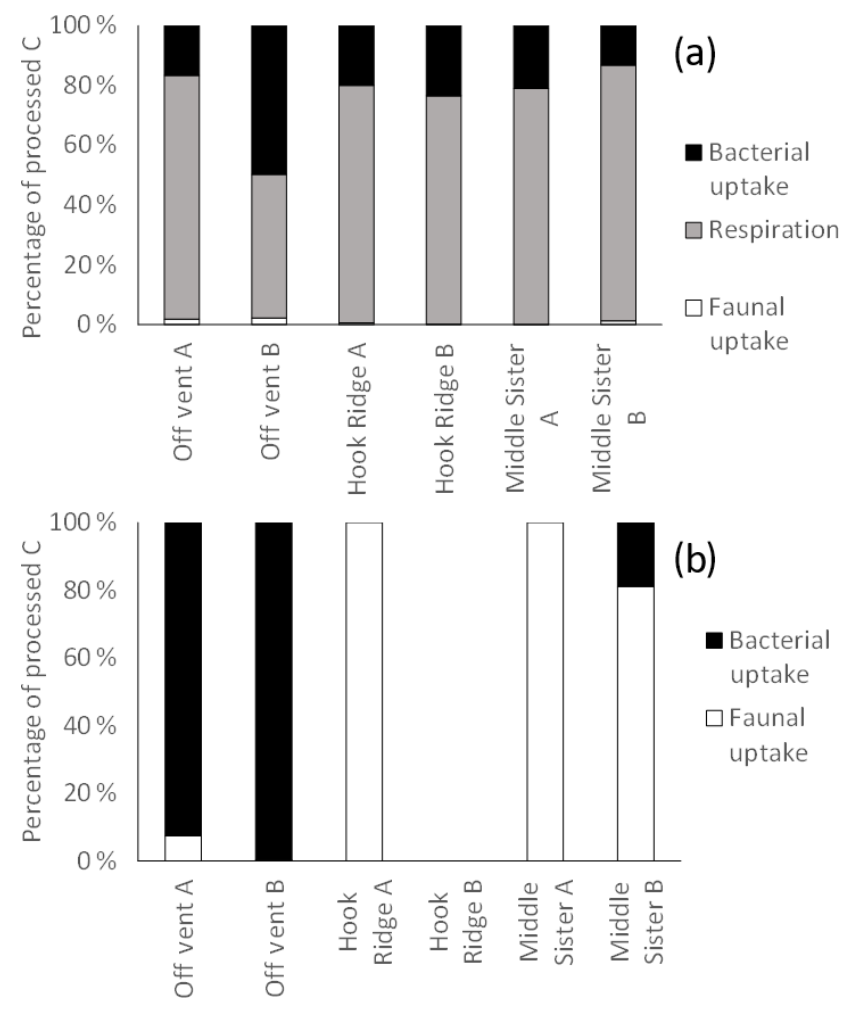

Figure 7. Distribution of biologically processed $\mathrm{C}$ between processes for the (a) algae addition experiments and (b) bicarbonate addition experiments. The absence of data represents the combination of the lack of sample and an undetectable faunal ${ }^{13} \mathrm{C}$ uptake.

Previous studies have suggested that SHVs tend to exhibit relatively high-biomass macrofaunal communities, sustained by the additional food source provided by chemosynthesis (Bernadino et al., 2012), and this leads to an expectation that the macrofauna may be particularly active in the processing of organic $\mathrm{C}$ in the sediment, in line with other food-rich environments such as estuaries and fjords (Moodley et al., 2000, 2005; Witte et al., 2003a). This was not the case in the algae addition experiments, with faunal uptake accounting for only $0.05 \%-2.2 \%$ of total biological ${ }^{13} \mathrm{C}$ processing (Fig. 7). This is similar to the role of faunal $\mathrm{C}$ uptake in overall $\mathrm{C}$ processing seen at deep, organic carbon-poor sites such as at a depth of $2170 \mathrm{~m}$ off north-western Spain (2.2\%, Moodley et al., 2002), or at a depth of $1552 \mathrm{~m}$ in the eastern Mediterranean (0.2\%, Moodley et al., 2005), and is lower than that at a depth of $4800 \mathrm{~m}$ on the Porcupine Abyssal Plain (1.5\%-26\%, Witte et al., 2003b). Such sites tend to have lower OC concentrations and lower macrofaunal biomass (Woulds et al., 2016) than was observed in the Bransfield Strait; therefore, the unusually small role of macrofaunal in $\mathrm{C}$ uptake in the Bransfield Strait may be due to low temperatures. Both low temperature and food scarcity have previously been observed to limit metabolic rates in polar environments (Brockington and Peck, 2001; Sommer and Port- ner, 2002). Another possible explanation for the rather small amount of macrofaunal $\mathrm{C}$ uptake at the Hook Ridge site may be that the macrofaunal community, which was composed almost entirely of non-vent-obligate, ambient Southern Ocean taxa (Bell et al., 2016b), had reduced levels of function due to the stress imposed by living at a site influenced by hydrothermal fluid. The toxicity and relatively high temperature of their environment (compared with non-hydrothermal Southern Ocean benthic settings) may have resulted in reduced $\mathrm{C}$ uptake activity. Therefore, macrofaunal biomass and $\mathrm{C}$ processing activities were limited by a hydrothermal flux that was sufficient to limit functioning and preclude the occurrence of some locally common taxa, but insufficient to sustain a high-biomass, vent-endemic macrofaunal community as seen in other SHVs (Bell et al., 2016b).

Siboglinid polychaetes, known to host chemosynthetic endosymbionts, were present at all study sites (Bell et al., 2016b), but were not found to make a substantial contribution to uptake of added ${ }^{13} \mathrm{C}$. This is to be expected in the algae addition experiments, as siboglinids would have direct access to algal C (except possibly via DOC). Most specimens recovered from the bicarbonate addition experiments also showed $\delta^{13} \mathrm{C}$ values indistinguishable from their natural signature, with one exception at the Middle Sister site which was enriched by $3.2 \%$ compared with the natural signature. The fact that siboglinids did not have a major role in $\mathrm{C}$ fixation and cycling in our experiments may have been partly due to their low abundances in experiment cores compared with patches where they were maximally abundant (Bell et al., 2016b), or because experiments were not long enough to allow for uptake by endosymbionts. Nonetheless, our findings show a much reduced role for siboglinids compared with suggestions made in previous publications. Aquilina et al. (2014) suggested that Siboglinum sp. at Hook Ridge may be sufficiently abundant to be conduits for a quantitatively meaningful flux of dissolved iron out of the sediment, and Bell et al. (2017b) found that they may be a key taxon facilitating input of chemosynthetic $\mathrm{C}$ into the food web. In agreement with the point made by Bell et al. (2016b), the spatial distribution of siboglinids is extremely patchy, and thus their role in benthic biogeochemical processes is spatially heterogeneous (Bell et al., 2017a, b).

\subsection{Carbon processing and SHVs as biogeochemical hot spots}

Respiration rates measured in the algae addition experiments were maximal at Middle Sister, and minimal at the Off Vent site (Fig. 2). Temperature is often recognised as a dominant control on benthic respiration rates (e.g. Moodley et al., 2005; Woulds et al., 2009), however these experiments were all conducted within $1{ }^{\circ} \mathrm{C}$ of each other, so temperature is unlikely to have driven differences in respiration rates. Instead, the differences between sites may have been driven by differences in bacterial biomass (Table 1), which was max- 

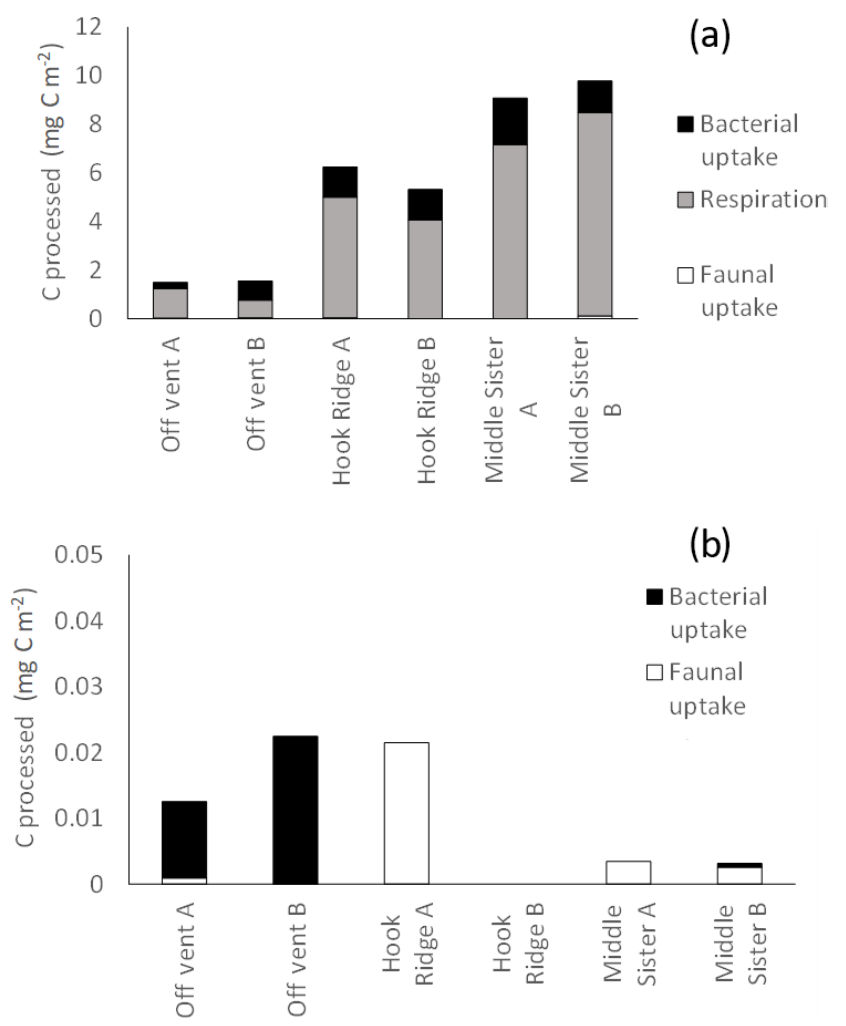

Figure 8. Total biological C processing during the (a) algae addition experiments and (b) bicarbonate addition experiments. The absence of data represents the combination of the lack of sample and an undetectable faunal ${ }^{13} \mathrm{C}$ uptake.

imal at Middle Sister and minimal at the Off Vent site. The bacteria are often found to account for a large majority of benthic community biomass, and are thus usually assumed to be responsible for the majority of benthic community respiration (e.g. Heip et al., 2001). The measured respiration rates were similar to those measured at $2170 \mathrm{~m}$ on the northwestern margin of Spain (Moodley et al., 2002), and on the Porcupine Abyssal Plain (Witte et al., 2003b), both of which were considerably deeper, and had lower sediment organic $\mathrm{C}$ concentrations, but higher bacteria biomass (Woulds et al., 2016). They were also lower than respiration rates measured at similar depths in the eastern Mediterranean (Moodley et al., 2005), and Arabian Sea (Woulds et al., 2009). These sites showed similar bacteria biomass to the Bransfield Strait, but were all considerably warmer $\left(7-14{ }^{\circ} \mathrm{C}\right.$, Woulds et al., 2016); therefore, the low ambient temperatures of the Southern Ocean appeared to reduce respiration rates.

It has been suggested that reducing benthic environments are often hot spots of faunal biomass and biogeochemical cycling due to the increased availability of labile food sources supplied by chemosynthesis (Bernardino et al., 2012). In this study, the hydrothermally active site Hook Ridge showed rates of respiration and bacterial uptake of algal $\mathrm{C}$ that were intermediate between the two non-hydrothermally ac- tive sites (Figs. 2, 3). Whilst comparison between sites is limited by very marked faunal patchiness, the amount of faunal uptake of algal ${ }^{13} \mathrm{C}$ at Hook Ridge was similar to that at the Off Vent control site, whereas that at Middle Sister was, in one replicate, considerably greater (Fig. 5). This suggests that SHVs are not necessarily biogeochemical cycling hot spots, as in the algae addition experiments the overall amount of added $\mathrm{C}$ processed by the benthic community was not greater than that observed at non-hydrothermal sites (Fig. 8). In line with this, biological processing of added $\mathrm{C}$ in the algae addition experiments did not show a major role for faunal $\mathrm{C}$ uptake as we hypothesised, but was instead dominated by respiration, as is typically observed at relatively deep, cold sites (Woulds et al., 2009). The Middle Sister site showed the greatest amount of biological processing of added algal $\mathrm{C}$, which was probably attributable to it having the greatest bacterial biomass and organic carbon concentrations, and the fact that the macrofaunal community, composed mostly of ambient Southern Ocean taxa, will have been functioning without the stress imposed by hydrothermal fluid.

\section{Conclusions}

The main fate of photosynthetic $\mathrm{C}$ was respiration in common with other deeper and more food-limited sites. The rates of respiration and $\mathrm{C}$ uptake by both macrofaunal and bacteria that we measured were comparatively low, and this is attributable to the low temperature of the experiments, and the toxicity and thermal stress caused by hydrothermal fluid. The hydrothermal site (Hook Ridge) in this study did not show more rapid $\mathrm{C}$ cycling than other similar experiments, as we hypothesised it would.

Benthic fixation of inorganic $\mathrm{C}$ was observed at all sites, and quantified at two out of three sites. While the rates were low compared with other similar experiments, the fact that the greatest amount of benthic $\mathrm{C}$ fixation occurred at the Off Vent site suggests that benthic $\mathrm{C}$ fixation may not be restricted to hydrothermal and other reducing settings. We suggest that it could be an important aspect of the marine C cycle, and warrants further study.

Data availability. Data sets can be found at https://doi.org/10.5285/98ccf93a-5e01-15e1-e053-6c86abc050ce (Woulds et al., 2019).

Author contributions. Experiments were conducted by $\mathrm{CW}$ and AGG. All authors contributed to analysis of samples, and commented on the paper.

Competing interests. The authors declare that they have no conflict of interest. 
Acknowledgements. The authors would like to thank Paul Tyler, as well as the officers and crew of RRS James Cook, and the onboard scientific party on cruise JC 55 . We would also like to thank Elisa Neame for assistance with extracting macrofauna.

Financial support. This research has been supported by Antarctic Science Ltd. and the Natural Environment Research Council (grant no. NE/J013307/1).

Review statement. This paper was edited by Tina Treude and reviewed by three anonymous referees.

\section{References}

Aquilina, A., Connelly, D. P., Copley, J. T., Green, D. R. H., Hawkes, J. A., Hepburn, L. E., Huvenne, V. A. I., Marsh, L., Mills, R. A., and Tyler, P. A.: Geochemical and Visual Indicators of Hydrothermal Fluid Flow through a Sediment-Hosted Volcanic Ridge in the Central Bransfield Basin (Antarctica), Plos One, 8, e54686, 2013.

Aquilina, A., Homoky, W. B., Hawkes, J. A., Lyons, T. W., and Mills, R. A.: Hydrothermal sediments are a source of water column Fe and $\mathrm{Mn}$ in the Bransfield Strait, Antarctica, Geochim. Cosmochim. Ac., 137, 64-80, 2014.

Bell, J. B., Aquilina, A., Woulds, C., Glover, A. G., Little, C. T. S., Reid, W. D. K., Hepburn, L. E., Newton, J., and Mills, R. A.: Geochemistry, faunal composition and trophic structure in reducing sediments on the southwest South Georgia margin, Royal Society Open Science, 3, 160284, 2016a.

Bell, J. B., Woulds, C., Brown, L. E., Sweeting, C. J., Reid, W. D. K., Little, C. T. S., and Glover, A. G.: Macrofaunal ecology of sedimented hydrothermal vents in the Bransfield Strait, Antarctica, Frontiers in Marine Science, 3, 32, 2016 b.

Bell, J. B., Reid, W. D. K., Pearce, D. A., Glover, A. G., Sweeting, C. J., Newton, J., and Woulds, C.: Hydrothermal activity lowers trophic diversity in Antarctic hydrothermal sediments, Biogeosciences, 14, 5705-5725, https://doi.org/10.5194/bg-145705-2017, 2017a.

Bell, J. B., Woulds, C., and Oevelen, D. v.: Hydrothermal activity, functional diversity and chemoautotrophy are major drivers of seafloor carbon cycling, Sci. Rep.-UK, 7, 12025, 2017 b.

Bernardino, A. F., Levin, L. A., Thurber, A. R., and Smith, C. R.: Comparative Composition, Diversity and Trophic Ecology of Sediment Macrofauna at Vents, Seeps and Organic Falls, Plos One, 7, e33515, 2012.

Boschker, H. T. S. and Middelburg, J. J.: Stable isotopes and biomarkers in microbial ecology, FEMS Microbiology Ecology, 40, 85-95, 2002.

Brockington, S. and Peck, L. S.: Seasonality of respiration and ammonium excretion in the Antarctic echinoid Sterechinus neumayeri, Marine Ecology Progress Series, 219, 159-168, 2001.

Colaco, A., Desbruyeres, D., and Guezennec, J.: Polar lipid fatty acids as indicators of trophic associations in a deep-sea vent system community, Mar. Ecol.-Evol. Persp., 28, 15-24, 2007.

Georgieva, M. N., Wicklund, H., Bell, J. B., Eilertsen, M. H., Mills, R. A., Little, C. T. S., and Glover, A. G.: A chemosynthetic weed: the tubeworm Sclerolinum contortum is a bipolar, cosmopolitan species, BMC Evolutionary Biology, 15, 280, 2015.

Heip, C. H. R., Duineveld, G., Flach, E., Graf, G., Helder, W., Herman, P. M. J., Lavaleye, M., Middelburg, J. J., Pfannkuche, O., Soetaert, K., Soltwedel, T., de Stigter, H., Thomsen, L., Vanaverbeke, J., and de Wilde, P.: The role of the benthic biota in sedimentary metabolism and sediment-water exchange processes in the Goban Spur area (NE Atlantic), Deep-Sea Res. Pt. II, 48, 3223-3243, 2001.

Klinkhammer, G. P., Chin, C. S., Keller, R. A., Dahlmann, A., Sahling, H., Sarthou, G., Petersen, S., and Smith, F.: Discovery of new hydrothermal vent sites in Bransfield Strait, Antarctica, Earth Planet. Sc. Lett., 193, 395-407, 2001.

Kunihiro, T., Veuger, B., Vasquez-Cardenas, D., Pozzato, L., Le Guitton, M., Moriya, K., Kuwae, M., Omori, K., Boschker, H. T. S., and van Oevelen, D.: Phospholipid-Derived Fatty Acids and Quinones as Markers for Bacterial Biomass and Community Structure in Marine Sediments, Plos One, 9, e96219, 2014.

Levin, L. A., Ziebis, W., Mendoza, G. F., Growney, V. A., Tryon, M. D., Brown, K. M., Mahn, C., Gieskes, J. M., and Rathburn, A. E.: Spatial heterogeneity of macrofauna at northern California methane seeps: influence of sulphide concentration and fluid flow, Mar. Ecol. Prog. Ser., 265, 123-139, 2003.

Levin, L. A., Mendoza, G. F., Konotchick, T., and Lee, R.: Macrobenthos community structure and trophic relationships within active and inactive Pacific hydrothermal sediments, Deep-Sea Res. Pt. II, 56, 1632-1648, 2009.

Main, C. E., Ruhl, H. A., Jones, D. O. B., Yool, A., Thornton, B., and Mayor, D. J.: Hydrocarbon contamination affects deep-sea benthic oxygen uptake and microbial community composition, Deep-Sea Res. Pt. I, 100, 79-87, 2015.

Masque, P., Isla, E., Sanchez-Cabeza, J. A., Palanques, A., Bruach, J. M., Puig, P., and Guillen, J.: Sediment accumulation rates and carbon fluxes to bottom sediments at the Western Bransfield Strait (Antarctica), Deep-Sea Res. Part II, 49, 921-933, 2002.

Middelburg, J. J.: Chemoautotrophy in the ocean, Geophys. Res. Lett., 38, L24604, 2011.

Molari, M., Manini, E., and Dell'Anno, A.: Dark inorganic carbon fixation sustains the functioning of benthic deep-sea ecosystems, Global Biogeochem. Cycles, 27, 212-221, 2013.

Moodley, L., Boschker, H. T. S., Middelburg, J. J., Pel, R., Herman, P. M. J., de Deckere, E., and Heip, C. H. R.: Ecological significance of benthic foraminifera: ${ }^{13} \mathrm{C}$ labelling experiments, Mar. Ecol. Prog. Ser., 202, 289-295, 2000.

Moodley, L., Middelburg, J. J., Boschker, H. T. S., Duineveld, G. C. A., Pel, R., Herman, P. M., and Heip, C. H. R.: Bacteria and foraminifera: Key players in a short-term deep-sea benthic response to phytodetritus, Mar. Ecol. Prog. Ser., 236, 23-29, 2002.

Moodley, L., Middelburg, J. J., Soetaert, K., Boschker, H. T. S., Herman, P. M., and Heip, C. H. R.: Similar rapid response to phytodetritus deposition on shallow and deep-sea sediments, J. Mar. Res., 63, 457-469, 2005.

Portail, M., Olu, K., Dubois, S. F., Escobar-Briones, E., Gelinas, Y., Menot, L., and Sarrazin, J.: Food-Web Complexity in Guaymas Basin Hydrothermal Vents and Cold Seeps, Plos One, 11, e0162263, 2016.

Sahling, H., Wallmann, K., Dahlmann, A., Schmaljohann, R., and Petersen, S.: The physicochemical habitat of Sclerolinum sp. 
at Hook Ridge hydrothernial vent, Bransfield Strait, Antarctica, Limnol. Oceanogr., 50, 598-606, 2005.

Sommer, A. M. and Portner, H. O.: Metabolic cold adaptation in the lugworm Arenicola marina: comparison of a North Sea and a White Sea population, Mar. Ecol. Prog. Ser., 240, 171-182, 2002.

Soto, L. A.: Stable carbon and nitrogen isotopic signatures of fauna associated with the deep-sea hydrothermal vent system of Guaymas Basin, Gulf of California, Deep-Sea Res. Pt. II, 56, 16751682, 2009.

Sweetman, A. K., Levin, L. A., Rapp, H. T., and Schander, C.: Faunal trophic structure at hydrothermal vents on the southern Mohn's Ridge, Arctic Ocean, Mar. Ecol. Prog. Ser., 473, 115131, 2013.

Sweetman, A. K., Thurber, A. R., Smith, C. R., Levin, L. A., Mora, C., Wei, C. L., Gooday, A. J., Jones, D. O. B., Rex, M. A., Yasuhara, M., Ingels, J., Ruhl, H. A., Frieder, C. A., Danovaro, R., Wurzberg, L., Baco, A. R., Grupe, B. M., Pasulka, A., Meyer, K. S., Dunlop, K. M., Henry, L.-A., and Roberts, M.: Major impacts of climate change on deep-sea benthic ecosystems, Elementa: Science of the Anthropocene, 5, 4, 2017.

Sweetman, A. K., Smith, C. R., Shulse, C. N., Maillot, B., Lindh, M., Church, M. J., Meyer, K., Oevelen, D. v., Stratmann, T., and Gooday, A. J.: Key role of bacteria in the short-term cycling of carbon at the abyssal seafloor, Limnol. Oceanogr., 9999, 1-20, 2018.

Thornhill, D. J., Wiley, A. A., Campbell, A. L., Bartol, F. F., Teske, A., and Halanych, K. M.: Endosymbionts of Siboglinum fjordicum and the phylogeny of bacterial endosymbionts in siboglinidae (Annelida), Biol. Bull., 214, 135-144, 2008.

van Oevelen, D., Bergmann, M., Soetaert, K., Bauerfeind, E., Hasemann, C., Klages, M., Schewe, I., Soltwedel, T., and Budaeva, N. E.: Carbon flows in the benthic food web at the deep-sea observatory HAUSGARTEN (Fram Strait), Deep-Sea Res. Pt. I, 58, 1069-1083, 2011.

van Oevelen, D., Soetaert, K., and Heip, C.: Carbon flows in the benthic food web of the Porcupine Abyssal Plain: The (un)importance of labile detritus in supporting microbial and faunal carbon demands, Limnol. Oceanogr., 57, 645-664, 2012.
Wegener, G., Bausch, M., Holler, T., Thang, N. M., Mollar, X. P., Kellermann, M. Y., Hinrichs, K. U., and Boetius, A.: Assessing sub-seafloor microbial activity by combined stable isotope probing with deuterated water and ${ }^{13} \mathrm{C}$-bicarbonate, Environ. Microbiol., 14, 1517-1527, 2012.

Witte, U., Aberle, N., Sand, M., and Wenzhofer, F.: Rapid response of a deep-sea benthic community to POM enrichment: an in situ experimental study, Mar. Ecol. Prog. Ser., 251, 27-36, 2003 a.

Witte, U., Wenzhofer, F., Sommer, S., Boetius, A., Heinz, P., Aberle, N., Sand, M., Cremer, A., Abraham, W.-R., Jorgensen, B. B., and Pfannkuche, O.: In situ experimental evidence of the fate of a phytodetritus pulse at the abyssal sea floor, Nature, 424, 763766, 2003b.

Woulds, C., Cowie, G. L., Levin, L. A., Andersson, J. H., Middelburg, J. J., Vandewiele, S., Lamont, P. A., Larkin, K. E., Gooday, A. J., Schumacher, S., Whitcraft, C., Jeffreys, R. M., and Schwartz, M. C.: Oxygen as a control on seafloor biological communities and their roles in sedimentary carbon cycling, Limnol. Oceanogr., 52, 1698-1709, 2007.

Woulds, C., Andersson, J. H., Cowie, G. L., Middelburg, J. J., and Levin, L. A.: The short-term fate of organic carbon in marine sediments: Comparing the Pakistan margin to other regions, DeepSea Res. Pt. II, 56, 393-402, 2009.

Woulds, C., Bouillon, S., Cowie, G. L., Drake, E., Middelburg, J. J., and Witte, U.: Patterns of carbon processing at the seafloor: the role of faunal and microbial communities in moderating carbon flows, Biogeosciences, 13, 4343-4357, https://doi.org/10.5194/bg-13-4343-2016, 2016.

Woulds, C., Bell, J. B., Glover, A., Bouillon, S., and Brown, L. S.: Benthic carbon fixation and cycling in diffuse hydrothermal and background sediments in the Bransfield Strait, Antarctica on cruise JC055, January to February 2011, British Oceanographic Data Centre, National Oceanography Centre, NERC, UK, https://doi.org/10.5285/98ccf93a-5e01-15e1-e0536c86abc050ce, 2019. 